\title{
A NEW ELEMENTARY PROOF OF WILKER'S INEQUALITIES
}

\author{
LU ZHANG AND LING ZHU
}

Abstract. In this note, we show a new elementary proof of Wilker's inequalities.

Key words and phrases: Wilker's inequalities.

\section{REFERENCES}

[1] J. B. WiLKer, E3306, The American Mathematical Monthly 96(1989), no.1, 55.

[2] J. S. Sumner, A. A. Jagers, M. Vowe, AND J. ANGLESIO, Inequalities involving trigonometric functions, The American Mathematical Monthly 98(1991), no.3, 264-267.

[3] B. N. GUO, B. M. QIAO, F. QI, AND W. LI, On new proof of Wilker's inequalities involving trigonometric functions, Mathematical Inequalities and Applications 1(2003), 19-22.

[4] I. PINELIS, L'Hospital rules for monotonicity and the Wilker-Anglesio Inequality, The American Mathematical Monthly 111(2004), 905-909. 